\title{
THE RELATIONSHIP BETWEEN IMMUNE RESPONSE AND HEAT SHOCK PROTEIN 70 (Hsp 70) UNDER COLD AND HEAT STRESSES IN NORFA CHICKENS
}

\author{
M.E. Soltan, A.A Enab, A.A Elfiky and Dina A. Selim \\ Dep. Of Poultry Production, Faculty Of Agriculture, Menufia Univ. Egypt
}

Received: May 31, 2017

Accepted: Jun. 4, 2017

\begin{abstract}
This study was carried out during the period from 2014 to 2015 in the Poultry Research Farm, Department of Poultry Production, Faculty of Agriculture, Menufia University, Shibin El- Kom, Egypt. The aim of this research was to study the relation between immune response and $\mathrm{Hsp} 70$ under different (cold $\left(10{ }^{\circ} \mathrm{C} / 76 \%\right.$ humidity) and heat $\left(37{ }^{\circ} \mathrm{C} / 57 \%\right.$ humidity)) stresses in order to predict the ability of chicks to tolerate these stresses in older ages. Total number of 322 males and females of Norfa chicken were used in 12 wks of age. Birds were divided into three groups according its immunity level (high, low and Control), the previous groups were subdivided into 6 subgroups (3 under heat stress and 3 under cold stress)by using a climatic chamber. These subgroups were subjected to different periods of exposure to stress (acute and chronic).

Results indicated that, in acute heat stress experiment, birds with high immunity levels which exposed to cold stress for 6 hours had the highest values of Hsp70 $(0.056 \pm 0.0045)$ with no significant differences with the other levels except for the birds with high immunity levels which exposed to high temperature stress for 3 hours. There were no significant differences among all exposure periods for the birds of low immunity level.

In chronic heat stress experiment, birds with high immunity levels, which exposed to high temperature for 6 days, had the highest values of Hsp70 (0.086 \pm 0.0031$)$ with significant differences $(\mathrm{P} \leq 0.05)$ compared with the other groups. Regarding the birds of the low immunity levels which exposed to cold temperature stress for 6 days had high value of Hsp70 more than the birds which exposed to 3 days.

As a conclusion, immunity level can be used as an indicator for heat tolerance for the birds exposed to cold or heat stress.
\end{abstract}

Key words: Immune response, Hsp 70, cold stress, heat stress, chickens.

\section{INTRODUCTION}

Stress represents the reaction of the animal organism (i.e., a biological response) to stimuli that disturb its normal physiological equilibrium or homeostasis.

When living organisms are exposed to thermal or non thermal stressors, the synthesis of most proteins is retarded; however, a group of highly conserved proteins known as HSPs are rapidly synthesized (Baqchi et al., 2001; Ogura et al., 2007; Park et al., 2007). These proteins are essential for organisms living at the edge of their thermal range. It is well documented that one of the most important functions of Hsps is to protect organisms from the toxic effects of heating (Arrigo, 2000). HSPs may play important roles in protein assembly and disassembly (Bukau et al., 2000; Hartl and Hayer-Hartl, 2002).

One relevant feature of Hsps is that overexpression of one or more Hsp genes confers protection against subsequent stress (McCormick et al., 2003; Zhang et al., 2007; Luh et al., 2007).

The protein acts as a molecular chaperone by binding to other cellular proteins, assisting intracellular transport, and folding into the proper secondary structures, thus preventing aggregation of protein 
during stress (Chirico et al., 1988; Hartl, 1996).

Heat shock proteins (Hsp) have been suggested to play a role in cellular protection under high ambient temperature, with a proposed relationship between the development of thermo tolerance and Hsp synthesis, especially Hsp70 (Hsp70; Lindquist and Craig, 1988).

The hormone-binding ability can be restored after a transient loss using an in vitro 5 protein system containing Hsp40, Hsp70, Hsp organizing protein, Hsp 90, and adenosine triphosphate (Hernandez et al., 2002).

According to the homology and molecular weights, Hsp can be classified into 3 main families: Hsp90 ( 85-90 kDa), Hsp70 ( 68$73 \mathrm{kDa}$ ), and low molecular weight Hsp ( 16-47 kDa; (Basu et al., 2002). Among the Hsp, Hsp70 is one of the most conserved and important protein families and has been studied extensively (Deane and Woo, 2005; Ming et al., 2010).

Discrepancies in susceptibility to different pathogens may be attributed to the effects of corticosteroids and heat shock proteins either on the particular pathology involved or on the immunological defense mechanisms (Siegel, 1980, 1985; Wampler et al., 2004; Malago et al., 2005; Nemeth et al., 2006).

These Hsp play an important role in the survival of stressed cells and the stabilization of the internal environment (Gabai et al., 1997).

Most research on Hsp in poultry has emphasized its association with body temperature (Wang and Edens, 1993; Yahav et al., 1997; Givisiez et al., 1999).

\section{MATERIALS AND METHODS}

A total number of 322 males and females of Norfa strain were used in this experiment. At 12 wks. of age, birds were selected divergently for high (HIR) and low (LIR) secondary immune response $7 \mathrm{~d}$ after i.m. immunization with $0.1 \mathrm{~mL}$ of a $0.25 \%$ suspension of SRBC and the treatments were continued up to $19 \mathrm{wks}$. The birds were divided into three groups as follows:-

a) High immune response group: the highest 154 chicks in antibody titers were taken from the base stock to form the high immune response group more than $(\bar{X}+S . E)$.

b) Low immune response group: the lowest 154 chicks in antibody titers $(\bar{X}-S . E)$ also, taken to form the low immune response group.

c) Control group: 14 both sexes birds were taken at random from the base stock (322 individuals) to serve as control group.

Birds of each group were kept in two climate chamber rooms where temperature, relative humidity and lightning were artificially controlled following the recommendations of the manufacturer. The measurements of each room are $6 \mathrm{~m}$ length, $3 \mathrm{~m}$ width and $3 \mathrm{~m}$ height. The rooms are equipped with an adjustable heating system with temperature ranged from $-5:+50{ }^{\circ} \mathrm{C}$. The rooms also have an adjustable humidity system to get relative humidity ranged from $10-90 \%$

Room 1:- Where cold stress was applied, the birds were transferred to the climatic champers and kept at $10{ }^{\circ} \mathrm{C} / 76 \%$ humidity. The birds exposed to acute cold stress for 3,6 , and $12 \mathrm{~h}$ and chronic cold stress for 3 and 6 days.

Room 2:- Where heat stress was applied, the chicks were transferred to the climatic champers and kept at $37{ }^{\circ} \mathrm{C} / 57 \%$ humidity. The birds exposed to acute heat stress for 3, 6, and 12 hours and chronic heat stress for 3 and 6 days.

Room 3:- Served as control and exposed to normal air temperature. Conventional diet and fresh clean water were available at all the experimental period. 
Blood samples were collected randomly from each group end of the experiment using serum separator tube (SST) until to allow samples to clot for two hours at room temperature or overnight at $4{ }^{\circ} \mathrm{C}$ before centrifugation for 15 minutes at $1000 \times \mathrm{g}$. Serum removed and assay immediately or aliquot and samples stored at $-20{ }^{\circ} \mathrm{C}$. Avoiding repeated freeze thaw cycles. Antibody presence in serum was evaluated by ELISA by using a commercial kit.

\section{Assay procedure}

All reagents and samples were brought to room temperature before use. Centrifuged the samples again after thawing before the assay. It was recommended that all samples and standards be assayed in duplicates.

1. All reagents and samples are prepared as directed in the previous sections.

2. The number of wells is determined to be used and put any remaining wells and the desiccant back into the pouch and seal the ziploc, store unused wells at $4^{\circ} \mathrm{C}$.

3. A blank well without any solution is setted.

4. $50 \mu \mathrm{l}$ of standard or sample per well are added. Standard need test in duplicate.

5. $50 \mu \mathrm{l}$ of HRP-conjugate are added to each well (not to Blank well), then $50 \mu \mathrm{l}$ antibody are added to each well. They are mixed well and then incubated for 1 hour at $37^{\circ} \mathrm{C}$.

6. Aspirated each well and wash, this process is repeated two times for a total of three washes. Washing is by filling each well with wash buffer $(200 \mu l)$ using a squirt bottle, multi-channel pipette, manifold dispenser, or auto washer, and it is let stand for 10 seconds, liquid is removed completely at each step and this is essential to good performance. After the last wash, any remaining wash buffer is removed by aspirating ordecanting. The plate is Inverted and blotted against clean paper towels.

7. $50 \mu \mathrm{l}$ of substrate $A$ and $50 \mu \mathrm{l}$ of substrate $B$ are add to each well, mixed well. It is incubated for 15 minutes at $37^{\circ} \mathrm{C}$. The plate is kept away from drafts and other temperature fluctuations in the dark.

8. $50 \mu \mathrm{l}$ stop solution is added to each well, gently tap the plate to ensure thorough mixing.

9. The optical density of each well is determined within 10 minutes, using a microplate reader set to $450 \mathrm{~nm}$.

This ELISA kit uses Sandwich-ELISA as the method. The Microelisa stripplate provided in this kit has been pre-coated with an antibody specific to HSP-70. Standards or samples are added to the appropriate Microelisa stripplate wells and combined to the specific antibody. Then a Horseradish Peroxidase (HRP)- conjugated antibody specific for HSP-70 is added to each Microelisa stripplate well and incubated. Free components are washed away. The TMB substrate solution is added to each well. Only those wells that contain HSP-70 and HRP conjugated HSP-70 antibody will appear blue in color and then turn yellow after the addition of the stop solution. The optical density (OD) is measured spectrophotometrically at a wavelength of $450 \mathrm{~nm}$. The OD value is proportional to the concentration of HSP-70. You can calculate the concentration of HSP-70 in the samples by comparing the OD of the samples to the standard curve by (MyBiosource.com).

\section{Statistical analysis:}

Data were analyzed by the least square analysis of variance using the General Linear Model Procedure (SAS, 2004). Significant differences among treatment means were tested using Duncan multiple range test (Duncan, 1955). 


\section{RESULTS AND DISCUSSION}

In experiment (1): The Hsp70 protein was an important part of the cell's machinery for protein folding and can act to protect cells from thermal or oxidative stress.

The effect of immunity levels, acute heat stress and its exposure periods ( $\bar{x} \pm$ SE ) on heat shock protein (Hsp70) were shown in (Table 1). Differences between birds of the high levels of immunity $(0.051 \pm 0.002)$ and the birds of the low group $(0.041 \pm 0.002)$ were significant $(P \leq 0.05)$. There were no significant differences among different exposure periods. This may be due to stimulation of increasing in Hsp70 protein and its mRNA expression after heat stress. These results were in agreement with that obtained by Franco-Jimenez and Beck (2007) who stated that, heat stress to $35^{\circ} \mathrm{C}$ for $1 \mathrm{~h}$ did not induce changes in Hsp70 liver expression.

The levels of Hsp70 increases as a consequence of increasing the periods of exposure for heat stress. This Hsp70 may be used as a good indicator of thermo tolerance.

Table (1): Effect of immunity levels, acute thermal stress and its periods of exposure on Hsp70 in Norfa chickens ( $\bar{X} \pm$ S.E).

\begin{tabular}{|c|c|}
\hline Immunity and thermal stress treatments & Hsp70 \\
\hline \multicolumn{2}{|c|}{ Immunity levels } \\
\hline High & $0.051 \pm 0.002^{a}$ \\
\hline Low & $0.041 \pm 0.002^{b}$ \\
\hline Control & $0.043 \pm 0.005^{\mathrm{ab}}$ \\
\hline \multicolumn{2}{|c|}{ Thermal stress } \\
\hline Cold & $0.047 \pm 0.002^{a}$ \\
\hline Heat & $0.045 \pm 0.002^{a}$ \\
\hline Control & $0.047 \pm 0.004^{\mathrm{a}}$ \\
\hline \multicolumn{2}{|c|}{ Periods of exposure } \\
\hline 3 hours & $0.041 \pm 0.003^{a}$ \\
\hline 6 hours & $0.048 \pm 0.003^{a}$ \\
\hline 12 hours & $0.049 \pm 0.003^{a}$ \\
\hline Control & $0.048 \pm 0.004^{a}$ \\
\hline
\end{tabular}

$a, b, c$ Means within the same column and the same treatment factors carry different small superscripts are significant at levels $\mathrm{P} \leq 0.05$ Hsp70 (ng/mg total protein) Heat Shock Protein. 
Interaction among immunity levels, acute heat stress and its exposure periods were shown in (Table 2). Significant differences $(P \leq 0.05)$ between birds of high and low immunity levels which exposed to cold stress were found. This may be due to confer protection from oxidative stress induced by cold stress by improving antioxidant capacity of immune organs. These results were in agreement with that obtained by Tamzil et al., (2013) who found that, exposure to acute heat stress $\left(40^{\circ} \mathrm{C}\right)$ for $0.5,1.0$ and $1.5 \mathrm{~h}$ increased Hsp70 expression in commercial chickens.

Table (2): The effect of interaction between immunity levels, acute thermal stress and its periods of exposure on heat shock protein (Hsp70) levels in Norfa chickens ( $\bar{X} \pm$ S.E).

\begin{tabular}{|c|c|c|}
\hline \multicolumn{2}{|c|}{ Immunity and thermal stress treatments } & $\mathrm{Hsp}_{70}$ \\
\hline \multicolumn{3}{|c|}{ Immunity levels $\times$ Thermal stress } \\
\hline \multicolumn{2}{|c|}{ Control } & $0.043 \pm 0.005^{a b}$ \\
\hline \multirow{2}{*}{ High immunity } & Cold & $0.054 \pm 0.003^{a}$ \\
\hline & Heat & $0.047 \pm 0.003^{a b}$ \\
\hline \multicolumn{2}{|c|}{ Control high immunity } & $0.054 \pm 0.005^{a}$ \\
\hline \multirow{2}{*}{ Low immunity } & Cold & $0.041 \pm 0.003^{b}$ \\
\hline & Heat & $0.042 \pm 0.003^{b}$ \\
\hline \multicolumn{2}{|c|}{ Contol low immunity } & $0.041 \pm 0.005^{b}$ \\
\hline \multicolumn{3}{|c|}{ Immunity levels $\times$ Periods of exposure } \\
\hline \multicolumn{2}{|c|}{ Control } & $0.043 \pm 0.005^{\text {bcd }}$ \\
\hline \multirow{3}{*}{ High Immunity } & 3 hours & $0.054 \pm 0.005^{a b}$ \\
\hline & 6 hours & $0.046 \pm 0.003^{a b c d}$ \\
\hline & 12 hours & $0.055 \pm 0.003^{a}$ \\
\hline \multicolumn{2}{|c|}{ Control high immunity } & $0.051 \pm 0.003^{a b c}$ \\
\hline \multirow{3}{*}{ Low immunity } & 3 hours & $0.041 \pm 0.005^{\mathrm{cd}}$ \\
\hline & 6 hours & $0.036 \pm 0.003^{d}$ \\
\hline & 12 hours & $0.041 \pm 0.003^{\mathrm{cd}}$ \\
\hline \multicolumn{2}{|c|}{ Control low immunity } & $0.047 \pm 0.003^{\mathrm{abcd}}$ \\
\hline \multicolumn{3}{|c|}{ Thermal stress $\times$ Periods of exposure } \\
\hline \multicolumn{2}{|c|}{ General Control } & $0.043 \pm 0.005^{a b}$ \\
\hline \multirow{3}{*}{ Cold } & 3 hours & $0.045 \pm 0.004^{a b}$ \\
\hline & 6 hours & $0.047 \pm 0.004^{a b}$ \\
\hline & 12 hours & $0.050 \pm 0.004^{a}$ \\
\hline \multirow{3}{*}{ Heat } & 3 hours & $0.037 \pm 0.004^{b}$ \\
\hline & 6 hours & $0.049 \pm 0.004^{a b}$ \\
\hline & 12 hours & $0.049 \pm 0.004^{a b}$ \\
\hline
\end{tabular}

a, b, c Means within the same column and the same treatment factors carry different small superscripts are significant at levels $\mathrm{P} \leq 0.05$ Hsp70 (ng/mg total protein) Heat Shock Protein. 
In contrast, the differences between birds of high and low immunity levels under high temperature acute stress were not significant. Heat shock proteins have been suggested to be involved in cellular protection in adverse situations, and these proteins may improve thermo tolerance of the bird. These results were in agreement with that obtained by Hao et al., (2012) who noticed that, no effects of over expression of Hsp70 in the jejuna mucosa under $36 \pm 1^{\circ} \mathrm{C}$ for $0,2,3,5$, and $10 \mathrm{~h}$ in broilers.

Birds with high immunity levels which exposed to 3 hours had higher levels of Hsp70 $(0.054 \pm 0.005)$ when compared with that of low immunity. The same result was found in case of 12 hours exposure periods. Moreover, the differences among the three exposure periods were not significant regardless of the levels of immunity. Hsp expression may be due to protective protein to regulate the immune function of chicks in cold stress conditions.

Members of the Hsp70 family were very strongly up regulated by heat stress. With regard to the interaction between acute heat stress and its exposure periods, there were significant differences $(P \leq 0.05)$ in the levels of Hsp70 between the birds that exposed to cold stress for 12 hours $(0.050 \pm 0.004)$ and the other group which exposed to high temperature stress $(0.037 \pm 0.004)$ for 3 hours. This lower response in the pre exposed HS group might be due to HS acclimation and could be indicative of acquired thermotolerance.

Heat shock proteins were extremely potent molecules, the importance of which to physiological and immunological processes was indicated by the high degree to which their structure and function were phylogenetically conserved.

The interactions among the three factors (immunity levels, acute heat stress and its exposure periods) were shown in (Table 3 , Fig 1). Birds with high immunity levels which exposed to cold stress for 6 hours had the highest values of $\mathrm{Hsp} 70(0.056 \pm 0.0045)$ with no significant differences with the other levels except for the birds with high immunity levels which exposed to high temperature stress for 3 hours. There were no significant differences among all exposure periods for the birds of low immunity level. This may be due to provide the link between innate and adaptive immune systems which may indicate that the time of exposure was not long enough or certain adaptation had already occurred in those pre exposed birds, reducing the amount of HSP70 needed for protection when the bird was exposed to HS. The results obtained by Zhao et al., (2014) who showed that, significantly decreased $(\mathrm{P}<0.05)$ in the mRNA levels of the Hsp70 gene of spleen and thymus under acute cold stress $(12 \pm 1){ }^{\circ} \mathrm{C}$ and kept for $1,3,6,12$, and $24 \mathrm{~h}$, but significantly increased $(\mathrm{P}<0.05)$ the mRNA levels of the Hsp70 gene of bursa of fabricius in all treatment groups.

In experiment (2): The induction of Hsp70 in response to stress serves to protect against the initial insult, augment recovery, and produce a state of resistance to subsequent stress.

The effect of immunity levels, chronic heat stress and its exposure periods $(\bar{X} \pm \mathrm{SE})$ on heat shock protein (Hsp70) were shown in (Table 4). Differences among the high levels of immunity and both of low and control groups were significant $(P \leq 0.05)$. The birds with high immunity level had the highest value of Hsp70 $(0.064 \pm 0.003)$ followed by the low immunity group $(0.044 \pm 0.003)$ and the lowest value for the control group (0.043 \pm 0.006$)$.

Heat stress induced remarkable changes in heat shock protein levels. There were no significant differences between the cold, heat and control groups for the effect of heat stress, taking into account that the heat stress group had the highest levels of Hsp70 $(0.057 \pm 0.0043)$. These results were in agreement with that obtained by Liew et al., 
(2003) who found that, the Hsp70 expression was not significant different during the heat exposure periods.

As the periods of exposure to heat stress increases, the levels of Hsp70 increases also. Hsp70 was increased by about $24 \%$ when the periods of exposure increased from 3 to 6 days. The control group had the lowest levels of Hsp70. Moreover, the differences among the exposure periods were not significant. The greater Hsp70 expression may be due to the proteins are involved in the stress caused by heat shock exposure in chickens.

The effect of cold and heat stress on immune response may depend on the exposure periods after the stress or at which immune response was determined. Interaction among immunity levels, chronic heat stress and its exposure periods were shown in (Table 5). Birds with high immunity levels which exposed to high temperature stress had the highest value of Hsp70 $(0.068 \pm 0.005)$, the same trend as in (Table 4), there were significant differences between heat and cold stress for the birds of low immunity. These results were in agreement with that obtained by Mohamed, Hanan (2006), Zhen et al., (2006) and Badri et al., (2008) who indicated that, quails under heat stress $39^{\circ} \mathrm{C}$ significantly higher Hsp 70 density in liver tissue.

Table (3): The interaction effect between immunity levels, acute thermal stress, its periods of exposure on (Hsp70) of Norfa chickens ( $\bar{X} \pm S . E)$.

\begin{tabular}{|c|c|c|c|}
\hline Levels & Thermal stress & Periods of exposure & Hsp 70 \\
\hline \multicolumn{3}{|c|}{ General control } & $0.0427 \pm 0.0045^{\text {abcde }}$ \\
\hline \multirow{6}{*}{ High immunity } & \multirow{3}{*}{ Cold } & $3 \mathrm{~h}$ & $0.0517 \pm 0.0045^{\mathrm{abcd}}$ \\
\hline & & $6 \mathrm{~h}$ & $0.0560 \pm 0.0045^{a}$ \\
\hline & & $12 \mathrm{~h}$ & $0.0540 \pm 0.0045^{\mathrm{ab}}$ \\
\hline & \multirow{3}{*}{ Heat } & $3 \mathrm{~h}$ & $0.0393 \pm 0.0045^{\text {bcde }}$ \\
\hline & & $6 \mathrm{~h}$ & $0.0543 \pm 0.0045^{\mathrm{ab}}$ \\
\hline & & $12 \mathrm{~h}$ & $0.0487 \pm 0.0045^{\mathrm{abcde}}$ \\
\hline \multicolumn{3}{|c|}{ Control high immunity } & $0.0537 \pm 0.0045^{\mathrm{abc}}$ \\
\hline \multirow{6}{*}{ Low immunity } & \multirow{3}{*}{ Cold } & $3 \mathrm{~h}$ & $0.0387 \pm 0.0045^{\text {cde }}$ \\
\hline & & $6 \mathrm{~h}$ & $0.0383 \pm 0.0045^{\mathrm{de}}$ \\
\hline & & $12 \mathrm{~h}$ & $0.0460 \pm 0.0045^{\mathrm{abcde}}$ \\
\hline & \multirow{3}{*}{ Heat } & $3 \mathbf{h}$ & $0.0337 \pm 0.0045^{c d}$ \\
\hline & & $6 \mathrm{~h}$ & $0.0430 \pm 0.0045^{\text {abcde }}$ \\
\hline & & $12 \mathrm{~h}$ & $0.0487 \pm 0.0045^{\text {abcde }}$ \\
\hline \multicolumn{3}{|c|}{ Control low immunity } & $0.0413 \pm 0.0045^{\text {abcde }}$ \\
\hline
\end{tabular}

$a, b, c, d, e, f$ Means within the same column and the same treatment factors carry different small superscripts are significant at levels $\mathrm{P} \leq 0.05$,

Hsp70 (ng/mg total protein) Heat Shock Protein. 


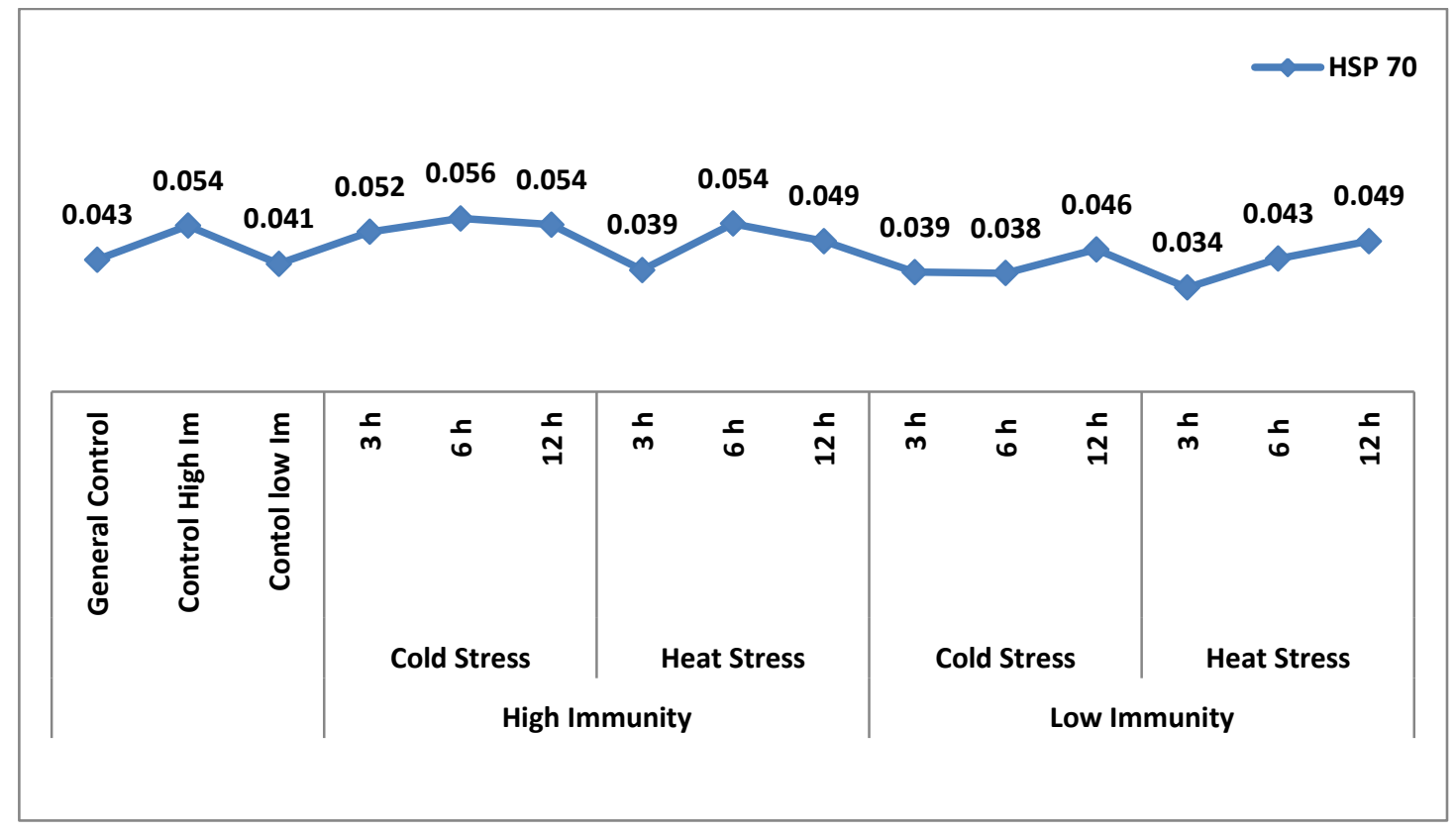

Fig. (1): The interaction between immunity levels, acute thermal stress and periods of exposure on heat shock protein (Hsp70) of Norfa chickens.

Table (4): Effect of immunity levels, chronic Thermal stress and its periods of exposure on Hsp70 in Norfa chickens ( $\bar{X} \pm$ S.E).

\begin{tabular}{|c|c|}
\hline Immunity and Thermal stress treatments & Hsp70 \\
\hline \multicolumn{2}{|c|}{ Immunity levels } \\
\hline High & $0.064 \pm 0.003^{a}$ \\
\hline Low & $0.044 \pm 0.003^{b}$ \\
\hline Control & $0.043 \pm 0.006^{b}$ \\
\hline \multicolumn{2}{|c|}{ Thermal stress } \\
\hline Cold & $0.055 \pm 0.0043^{a}$ \\
\hline Heat & $0.057 \pm 0.0043^{a}$ \\
\hline Control & $0.048 \pm 0.0061^{a}$ \\
\hline \multicolumn{2}{|c|}{ Periods of exposure } \\
\hline 3 days & $0.050 \pm 0.004^{\mathrm{ab}}$ \\
\hline 6 days & $0.062 \pm 0.004^{a}$ \\
\hline Control & $0.048 \pm 0.006^{\mathrm{ab}}$ \\
\hline
\end{tabular}

a, b, c Means within the same column and the same treatments factors carry different small superscripts are significant at levels $\mathrm{P} \leq 0.05$

Hsp70 (ng/mg total protein) Heat Shock Protein; 
Table (5): The effect of interaction between immunity levels, chronic thermal stress and its periods of exposure and heat shock protein levels in Norfa chickens $(\bar{X} \pm$ S.E).

\begin{tabular}{|c|c|c|}
\hline \multicolumn{2}{|c|}{ Immunity and heat stress treatments } & Hsp70 \\
\hline \multicolumn{3}{|c|}{ Immunity levels $\times$ Thermal Stress } \\
\hline \multicolumn{2}{|c|}{ Control } & $0.043 \pm 0.007^{b}$ \\
\hline \multirow{2}{*}{ High immunity } & Cold & $0.066 \pm 0.005^{a}$ \\
\hline & Heat & $0.068 \pm 0.005^{a}$ \\
\hline \multicolumn{2}{|c|}{ Control high immunity } & $0.054 \pm 0.007^{\mathrm{ab}}$ \\
\hline \multirow{2}{*}{ Low immunity } & Cold & $0.045 \pm 0.005^{b}$ \\
\hline & Heat & $0.046 \pm 0.005^{b}$ \\
\hline \multicolumn{2}{|c|}{ Contol low immunity } & $0.041 \pm 0.007^{b}$ \\
\hline \multicolumn{3}{|c|}{ Immunity levels $\times$ Periods of exposure } \\
\hline \multicolumn{2}{|c|}{ Control } & $0.043 \pm 0.006^{c}$ \\
\hline \multirow{2}{*}{ High Immunity } & 3 days & $0.062 \pm 0.004^{b c}$ \\
\hline & 6 days & $0.073 \pm 0.004^{a b}$ \\
\hline \multicolumn{2}{|c|}{ Control high immunity } & $0.054 \pm 0.006^{a}$ \\
\hline \multirow{2}{*}{ Low immunity } & 3 days & $0.039 \pm 0.004^{c}$ \\
\hline & 6 days & $0.051 \pm 0.004^{c}$ \\
\hline \multicolumn{2}{|c|}{ Control low immunity } & $0.041 \pm 0.006^{b c}$ \\
\hline \multicolumn{3}{|c|}{ Thermal Stress $\times$ Periods of exposure } \\
\hline \multicolumn{2}{|c|}{ General Control } & $0.043 \pm 0.008^{b}$ \\
\hline \multirow{2}{*}{ Cold } & 3 days & $0.055 \pm 0.005^{\mathrm{ab}}$ \\
\hline & 6 days & $0.056 \pm 0.005^{a b}$ \\
\hline \multirow{2}{*}{ Heat } & 3 days & $0.046 \pm 0.005^{b}$ \\
\hline & 6 days & $0.068 \pm 0.005^{a}$ \\
\hline
\end{tabular}

$a, b, c$ Means within the same column and the same treatments factors carry different small superscripts are significant at levels $\mathrm{P} \leq 0.05$,

Cold: Cold stress ( $\left.10^{\circ} \mathrm{C} / \mathrm{RH}: 76 \%\right)$; Heat: Heat stress (37으 / RH: $57 \%$ ),

Hsp70 (ng/mg total protein) Heat Shock Protein. 
Birds with high immunity levels which exposed to stress for 6 days had the highest value of Hsp70 $(0.073 \pm 0.004)$, the same trend as in (Table 4), significant differences were observed with the birds of low immunity levels which exposed to stress for 3 days or 6 days.

Regarding the interaction between chronic heat stress and its periods of exposure, birds which exposed to high temperature stress for 6 days had the highest value of Hsp70 (0.068 \pm 0.005$)$, significant differences were noted with the birds which exposed to high temperature stress for 3 days.

The interactions among the three factors (immunity levels, heat stress and its exposure periods) were shown in (Table 6, Fig 2). Birds with high immunity levels which exposed to high temperature stress for 6 days had the highest values of Hsp70 $(0.086 \pm 0.0031)$ with significant differences compared with the other groups. Regarding the birds of the low immunity levels which exposed to cold temperature stress for 6 days had high value of Hsp70 more than the birds which exposed to the same stress for only 3 days. These results were in agreement with that obtained by Givisiez et al., (2001) and Soleimani et al., (2012) who noticed that, Hsp70 levels increased significantly during heat stress in the birds.

Conclusion: This study revealed that there is a strong relation between chicken with high immunity level and Hsp 70 in heat resistance. Birds with high immunity level had a better heat shock protein 70 as compared to birds with low immunity level.

Table (6): The interaction between immunity levels, chronic thermal stress, its periods of exposure on (Hsp70) of Norfa chickens ( $\bar{X} \pm$ S.E).

\begin{tabular}{|c|c|c|c|}
\hline Levels & Thermal stress & $\begin{array}{l}\text { Periods of } \\
\text { exposure }\end{array}$ & Hsp 70 \\
\hline \multicolumn{3}{|c|}{ General control } & $0.043 \pm 0.0031^{\text {def }}$ \\
\hline \multirow{4}{*}{ High immunity } & \multirow{2}{*}{ Cold } & $3 d$ & $0.073 \pm 0.0031^{b}$ \\
\hline & & $6 \mathrm{~d}$ & $0.059 \pm 0.0031^{c}$ \\
\hline & \multirow{2}{*}{ Heat } & $3 d$ & $0.050 \pm 0.0031^{\text {cde }}$ \\
\hline & & $6 \mathrm{~d}$ & $0.086 \pm 0.0031^{a}$ \\
\hline \multicolumn{3}{|c|}{ Control high immunity } & $0.054 \pm 0.0031^{c}$ \\
\hline \multirow{4}{*}{ Low immunity } & \multirow{2}{*}{ Cold } & $3 \mathrm{~d}$ & $0.038 \pm 0.0031^{f}$ \\
\hline & & $6 \mathrm{~d}$ & $0.052 \pm 0.0031^{\mathrm{cd}}$ \\
\hline & \multirow{2}{*}{ Heat } & $3 d$ & $0.041 \pm 0.0031^{\text {ef }}$ \\
\hline & & $6 \mathrm{~d}$ & $0.050 \pm 0.0031^{\text {cde }}$ \\
\hline \multicolumn{3}{|c|}{ Control low immunity } & $0.041 \pm 0.0031^{\text {ef }}$ \\
\hline
\end{tabular}

$a, b, c, d, e, f$ Means within the same column and the same treatments factors carry different small superscripts are significant at levels $P \leq 0.05$,

Hsp70 (ng/mg total protein) Heat Shock Protein. 


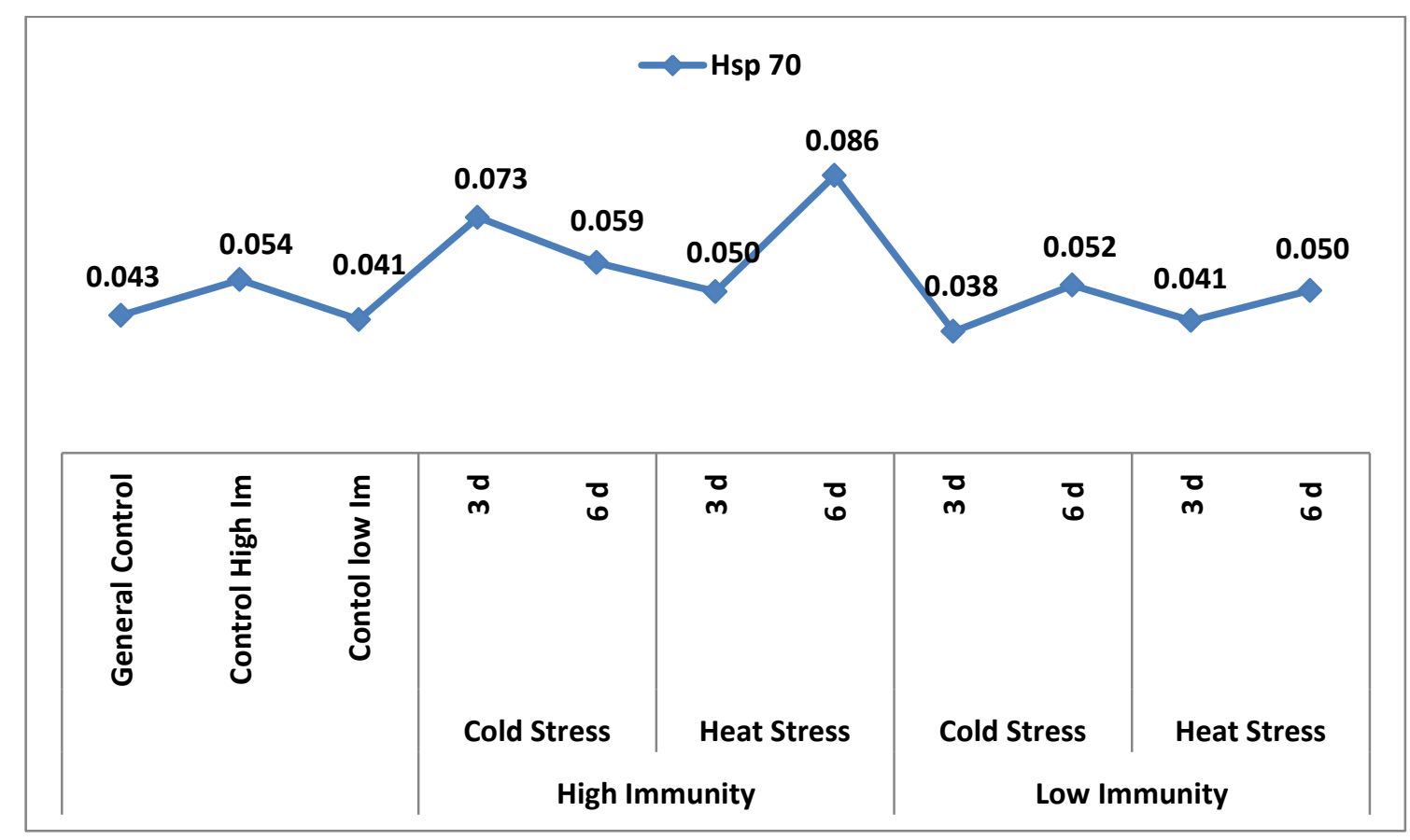

Fig (2): The interaction between immunity levels, chronic thermal stress and periods of exposure on heat shock protein (Hsp70) of Norfa chickens.

\section{REFERENCES}

Arrigo, A. P. (2000). HSPs as novel regulators of programmed cell death and tumorigenicity. Path. Bio., 48:280-288.

Baqchi, M., M. Ireland, M. Katar and $\mathrm{H}$. Maisel. (2001). Heat shock proteins of chicken lens. J. Cell. Biochem., 82(3):409-414.

Basu, N., A. E. Todgham, P. A. Ackerman, M. R. Bibeau, K. Nakano, P. M. Schulte, and G. K. Iwama (2002). Heat shock proteingenes and their functional significance in fish. Gene 295:173-183.

Bukau, B., E. Deuerling, C. Pfund and E. A. Craig (2000). Getting newly synthesized proteins into shape. Cell, 101(2):119-122.

Chirico, W. J., M. G. Waters and G. Blobel. (1988). 70K heat shock related protein stimulate protein translocation into microsomes. Nature, 332:805-810.

Badri, F.A., S.A. Abdel-Fattah, Y.M. ElHommosany, Maie F.M. Ali and Nermin M. Abdel-Gawad, (2008). Immunocompetence, Hepatic heat shock protein 70 and physiological responses to feed restriction and heat stress in two body weight lines of japanese quail. International Journal of Poultry Science, 7: 174-183.

Deane, E.E. and N.Y.S. Woo (2005). Cloning and characterization of the HSP70 multigene family from silver sea bream: modulated gene expression between warm and cold temperature stress. Biochemical and Biophysical Research Communications 330, 776783.

Duncan, D.B. (1955). Multiple range and multiple $\mathrm{F}$ tests. Biometerics, 11:1-42.

Franco-Jimenez, D. J. and M. M. Beck (2007). Physiological changes to transient exposure to heat stress observed in laying hens. Poultry Sci., 86:538-544

Gabai, V. L., A. B. Meriin, D. D. Mosser, A. W. Caron, S. Rits, V. I. Shifrin and M. Y. Sherman (1997). HSP70 prevents activation of stress kinase-A novel pathway of cellular thermotolerance. J. Biol. Chem., 272:18033-18037. 
Givisiez, P. E. N., J. A Ferro, M. I. T. Ferro, S. N. Kronka, E. Decuypere and M. Macari (1999). Hepatic concentration of heat shock protein $70 \mathrm{kD}$ (Hsp70) in broilers subjected to different thermal treatments. Br. Poult. Sci., 40:292-296.

Givisiez, P.E.N., M.M. Da Silva, C.M. Mazzi, M.I.T. Ferro, J.A. Ferro, E. Gonzales and M. Macari (2001). Heat or cold chronic stress affects organ weights and Hsp70 levels in chicken embryos. Canadian Journal of Animal Science, 81: 83-87.

Hao, Y., X. H. Gu and X. L. Wang (2012). Overexpression of heat shock protein 70 and its relationship to intestine under acute heat stress in broilers: 1. Intestinal structure and digestive function. Poultry Sci., 91:781-789.

Hartl, F. U. (1996). Molecular chaperones in cellular protein folding. Nature, 381:571580.

Hartl, F. U. and M. Hayer-Hartl. (2002). Molecular chaperones in the cytosol: from nascent chain to folded protein. Science, 295(5561):1852-1858.

Hernandez, M.P., W.P. Sullivan and D.O. Toft (2002). The assembly and intermolecular properties of thehsp70Hop-hsp90 molecular chaperone complex. J Biol Chem 277, 38294-38304.

Liew, P. K., I. Zulkifli, M. Hair-Bejo, A. R. Omar and D. A. Israf (2003). Effects of early age feed restriction and heat conditioning on heat shock protein 70 expression, resistance to infectious bursal disease, and growth in male broiler chickens subjected to heat stress. Poultry Sci., 82:1879-1885.

Lindquist, S. and E. A. Craig (1988). The heat shock proteins. Annu. Rev. Genet. 22:631-637.

Luh, S.P., P.H. Kuo, T.F. Kuo, T.P. Tsai, T.C. Tsao, J.Y. Chen, C.H. Tsai and P.C. Yang (2007). Effects of thermal preconditioning on the ischemia reperfusion-induced acute lung injury in minipigs. Shock 28 (5):615-622.

Mohamed, Hanan, S. M. (2006). Some Physiological and Immunological
Measurements in Local Breed of Chickens after Heat Stress. Ph.D. Thesis, Fac. Agric., Cairo Univ., Egypt, $189 \mathrm{p}$.

Malago, J. J., J. F. J. G. Koninkx, P. C. J. Tooten, E. A. van Liere and J. E. van Dijk (2005). Anti-inflammatory properties of heat shock protein 70 and butyrate on Salmonella-induced interleukin-8 secretion in enterocyte-like Caco-2 cells. Clin. Exp. Immunol., 141:62-71.

McCormick, P.H., G. Chen, S. Tlerney, C.J. Kelly and D.J. Bouchier-Hayes (2003). Clinically relevant thermal preconditioning attenuates ischemiareperfusion injury. J Surg Res., 109:2430.

Ming, J., J. Xie, P. Xu, W.B. Liu, X.P. Ge, B. Liu, Y.J. He, Y.F. Cheng, Q.L. Zhou and L.K. Pan (2010). Molecular cloning and expression of two HSP70 genes in the Wuchang bream (MegalobramaamblycephalaYih). Fish Shellfish Immunol., 28:407-418.

MyBiosource. Com. Chicken heat shock protein (Hsp 70) ELISA Kit. Amanual for quantitative determination of chicken heat shock protein 70 (Hsp 70) concentrations in serum, plasma and tissue homogenates. Catalog number. MBS7039024.

Nemeth, E., S. Fajdiga, J. Malago, J. Koninkx, P. Tooten and J. van Dijk (2006). Inhibition of Salmonella-induced IL-8 synthesis and to nonstarter lactobacilli. Int. J. Food Microbiol., 112:266-274.

Ogura, Y., Y. Naito, T. Tsurukawa, N. Ichinoseki-Sekine, N. Saga, T. Sugiura and S. Katamoto (2007). Microwave hyperthermia treatment increases heat shock proteins in human skeletal muscle. Br. J. Sports Med. 41: 453-455.

Park, H., I. Y. Ahn and H. E. Lee (2007). Expression of heat shock protein 70 in the thermally stressed antarctic clam Laternula elliptica. Cell Stress Chaperones, 12(3): 275-282. 
SAS, (2004). SAS User's Guide: Statistics. SAS Inst. Inc., Cary, N.C. USA.

Siegel, H. S. (1980). Physiological stress in birds. Bioscience, 30:529-534.

Siegel, H. S. (1985). Immunological responses as indicators of stress. World's Poult. Sci. J., 41:215-230.

Soleimani, A. F., I. Zulkifli, M. Hair-Bejo, A. R. Omar and A. R. Raha (2012). The role of heat shock protein 70 in resistance to Salmonella enteritidis in broiler chickens subjected to neonatal feed restriction and thermal stress. Poultry Sci, 91:340-345. doi: 10.3382/ps.2011-01703.

Tamzil, M.H., R.R. Noor, P.S. Hardjosworo, W. Manalu and C. Sumantri (2013). Acute heat stress responses of three lines of chickens with different heat shock protein (hsp)-70 genotypes. International Journal of Poultry Science 12 (5): 264272.

Wampler, J. L., K. P. Kim, Z. Jaradat and A. K. Bhunia (2004). Heat shock protein 60 acts as a receptor for the Listeria adhesion protein in Caco-2 cells. Infect. Immun. 72:931-936.

Wang, S. Y. and F. W. Edens (1993). Stress-induced heat-shock protein synthesis in peripheral leucocytes of turkeys, Meleagris gallopavo. Comp. Biochem. Physiol. 106B:621-628.

Yahav, S., A. Shamay, G. Horev, D. BarIlan, O. Genina and M. Friedman-Einat. (1997). Effect of acquisition of improved thermotolerance on the induction of heat shock proteins in broiler chickens. Poultry Sci., 76:1428-1434.

Zhao, F.Q., Z. W. Zhang, J. P. Qu, H. D. Yao, M. Li, S. Li and S. W. Xu (2014). Cold stress induces antioxidants and Hsps in chicken immune organs. Cell stress and chaperones 19:635 - 648.

Zhang, H.Y., N.H. Lv, Y. Xie, G.H. Guo, J.H. Zhan and J. Chen (2007). Protection of heat shock preconditioning on acute gastric mucosal lesion in scalded rats and its mechanism. Zhonghua Shao Shang Za Zhi, 23(1):58-61.

Zhen, F. S., H. I. Du, H. P. Xu, Q. B. Luo and X. Q. Zhang (2006). Tissue and allelic specific expression of hsp70 gene in chickens: basal and heat stress induced mRNA level quantified with realtime reverse transcriptase polymerase chain reaction. Br. Poult. Sci., 47:4, 449-455. 


\section{العلاقة بين الاستجابه المناعية و بروتين الصدمة الحرارية 70 تحت تأثير إجهاد البرودة والحرارة في دجاج النورفا لين الهنها}

\section{محمد السبد سلطان ، أحمد عبدالوهاب عنب ، عبدالمنعم عبدالحليم الفقى ، دينا عبدالقتاح سليم}

قسم إنتاج الدواجن ـ كلية الزراعة . جامعة المنوفية

الملخص العربي

أجريت هذه التجربة خلال الفترة من 2014 إلى 2015م بمزرعة بحوث الدواجن التابعة لقسم إنتاج الدواجن،كلية الزراعة، جامعة المنوفية، شبين الكوم، مصر • والهـف من البحث دراسة العلاقة بين الاستجابة المناعية و بروتين الصدمة

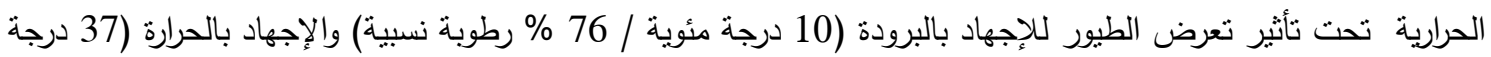

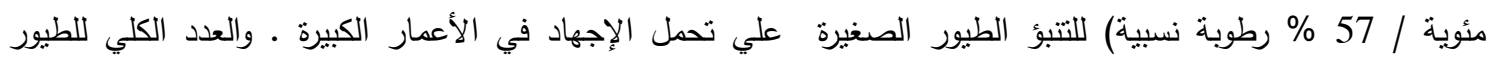

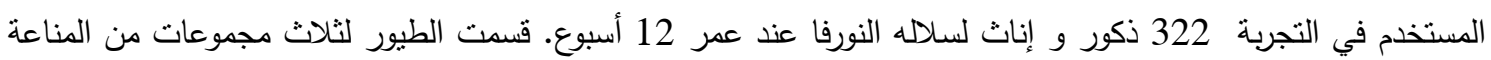

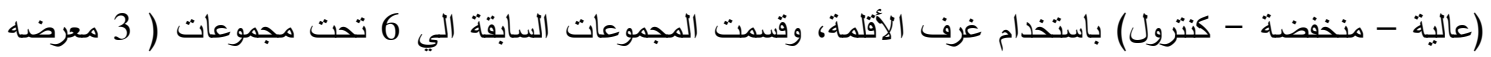
لإجهاد الحرارة ، و 3 معرضه لإجهاد البرودة). وهذه المجموعات تحت نظامي تعريض(حاد الفاد و مزمن).

تم تلخيص النتائج المتحصل عليها كما يلي:بالنسبة للتعرض للإجهاد الحاد، سجلت الطيور ذات المناعة العالية والتى تعرضت للإجهاد بالبرودة لمدة 6 ساعات أعلى

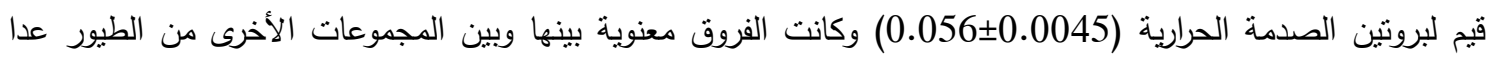
الطيور عالية المناعة والتى تعرضت للإجهاد بالحرارة لمدة 3 ساعات. بالنسبة للطيور منخفضة المناعة كانت الفروق بين كل المستويات غير معنوية.

بالنسبة للتعرض للإجهاد المزمن، الطيور عالية المناعة والتى تعرضت للإجهاد بالحرارة العالية لمدة 6 أيام قد سجلت أعلى مستويات لبروتين الصدمة الحرارية (0.086_0031) مع فروق معنوية بينها وبين المجموعات الأخرى. بالنسبة للطيور منخفضة المناعة والتى تعرضت للإجهاد بالبرودة لمدة 6 أيام قد سجلت مستويات عالية من بروتين الصدمة الحرارية أكثر من الطيور التى تعرضت لنفس الإجهاد ولكن لمدة 3 أيام فقط.

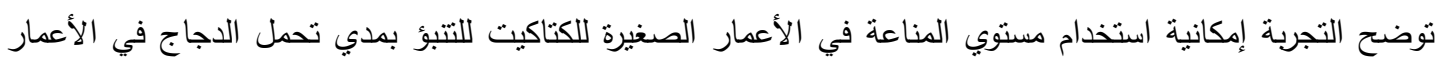
الكبيرة للإجهاد الحراري عن طريق إفراز بروتينات الصدمة الحرارية 70 للطيور المعرضة لإجهادي الحربة الحرارة والبرودة. 